\title{
Literature Review About the Effect of Intellectual Capital on Firm Value
}

\author{
Preatmi Nurastuti ${ }^{1}$, Surachman $^{2}$, Rofiaty $^{3}$, Siti Aisjah $^{4}$ \\ ${ }^{1}$ Pelita Bangsa University, Indonesia \\ ${ }^{2,3,4}$ Brawijaya University, Malang, Indonesia \\ \{Preatmi.nurastuti@pelitabangsa.ac.id', Surachman.feub@gmail.com², rofiaty@yahoo.com³ \\ aisjahsiti@gmail.com ${ }^{4}$ \}
}

\begin{abstract}
This literature review reviews the relationship between intellectual capital and firm value. Research has been attempted and carried out by researchers from various countries about intellectual capital and firm value, with value added intellectual capital as a framework of intellectual capital. Research on this theme shows different and varied results, there are those that show positive and negative relationships, there are those that show no relationship between intellectual capital and firm value. Empirical studies have not shown the same common ground, so this literature review is carried out. Literature review is expected to benefit researchers who will examine the same theme.
\end{abstract}

Keywords: intellectual capital, VAIC, firm value

\section{Introduction}

Empirical research on intellectual capital has been initiated since the 1980s with the inclusion of communication technology as forming the knowledge economy. Intellectual capital is intangible capital. One factor that emphasizes the importance of intellectual capital in companies is the change in management focus from tangible capital to intangible capital when considering the processes of creating value in the company. Efforts have been made by academics, practitioners and researchers on this matter, but have not shown a common ground. This article seeks to present an overview of various literature and studies related to the relationship of intellectual capital. The results of this study are expected to be a strong basis for further research and can contribute to the existing literature. This article is divided into 5 parts, the first part presents an introduction related to intellectual capital and firm value. The second part presents a review of the literature on intellectual capital. The third section presents VAIC. The fourth section presents the relationship of intellectual capital and firm value. The fifth section presents the discussions and conclusions related to the reviews presented.

\section{Results and Discussions}

\subsection{Intellectual capital}

In the early 1980 s the emergence of intangible value which was generally understood as goodwill. In the mid 1980s the emergence of the information era with the entry of information 
technology that shaped the knowledge economy. In 1995, Nonaka and Takeuchi demonstrated the creation of corporate knowledge focused on intellectual capital. Intellectual capital became popular as a topic of research in the following years. Previous researchers worked on what is meant by intellectual capital. Intellectual capital is the company's capital to win the competition (Bontis, 1996). Intellectual capital is a hidden asset to maintain competitive advantage (Roos and Roos, 1997). Intellectual capital is knowledge, information, intellectual capital and experience (Steward, 1997). Intellectual capital clarifies the difference in book value and market value of a company (Edvinsson and Malone, 1997). Intellectual capital is company capital that can be converted into corporate value (Sveiby, 1998). Intellectual capital is company capital that utilizes knowledge effectively (Bontis, 1999).

The results of empirical studies show the importance of intellectual capital. We can say that the greatest benefit of managing Intellectual capital is managing firm value creation (Roos et al., 1997). Previous researchers claim that companies are beginning to realize that technologybased competitiveness is temporary and that sustainable profits depend on managing intellectual capital, namely intangible resources (Johansen et al., 1999a). Other empirical research claims that sustainable profits depend on the ability of companies to create value through knowledge management (Lev, 2001; Sveiby, 2001). Companies that can manage intellectual capital properly will be able to drive the value of the firm and competitive advantage will increase (Bounfour, 2009).

\subsection{Value Added Intellectual Capital}

Current research has developed not only on the importance of managing Intellectual capital, but also on its measurement. The value platform model was developed by Petrash (1996) by classifying intellectual capital as an accumulation of human capital, organizational capital and customer capital. Steward (1997) classifies intellectual capital as an accumulation of human capital, structural capital, customer capital. In 1999, Pulic proposed Value Added Intellectual Capital (VAIC) as a research framework on Intellectual Capital by classifying efficiency of human capital, structural capital efficiency and employee capital efficiency. Value Added Intellectual Capital (VAIC) is a very popular and developing model in many countries. Calculation of Value Added Intellectual Capital (VAIC) revealed is the sum of three elements, namely efficiency of human capital, structural capital efficiency and capital employee efficiency.

Value Added Intellectual Capital (VAIC) has limitations because it does not include relation capital and innovation capital. To overcome this limitation, studies are conducted to expand the value added intellectual capital. Intellectual capital management allows companies to innovate and express signals to the market about growth opportunities so that market value increases (Ståhle et al., 2011; Sardo and Serrasqueiro., 2017; Smriti \& Das, 2018). The modified and expanded value added intellectual capital (VAIC) model in the study was applied by adding relation capital and innovation capital. Proxy of relation capital is the cost of marketing and advertising, while innovation capital is proxied by $R \& D$ expenses. So for value added modification is the sum of operating profit, depreciation, amortization, employee salaries and wages, marketing and advertising expenses, R\&D expenses (Xu, J., \& Liu, F., 2020).

\subsection{Intellectual Capital and Company Value}

The first approach to the theory of value is carried out by M.J. Langeveld, 1957 by arguing that value is something that has a price. Rokech's research, 1973 shows that values are about what 
should and shouldn't be. Meglino and Ravlin, 1998 say that value is about the result of how someone interprets information. Over time, the question arises, what is meant by the value of the company. Jensen and Meckling, 1976 show that determining the value of a company in achieving its goals is always strongly associated with the value of its shareholders. The traditional view of the company and the view of Jensen and Meckling still focus on shareholders as the most important group because it has the highest bargaining power in the company. The traditional view of the concept of shareholder value as an explanation for company value is opposed by a group of researchers who believe that corporate value does not have to be based on shareholders but must include all stakeholder groups.

Johnson et al., 1999 shows knowledge management can create value. Bounfour, 2003 suggested that intellectual capital can drive value. Research Bukh, 2003 shows that the disclosure of intellectual capital is part of the framework of the process of creating corporate value. Nuryaman, 2015 shows that there is an influence of intellectual capital on firm value. Alste Kalvionyte and Renata Korsakiene, 2016 showed that intellectual capital is a key factor in creating added value for the company. Costin Daraban, 2017, the importance of managing intangible assets to create value. Kyonok Kim, 2017, economic value is no longer based only on material goods but on the creation of intellectual capital which plays an important role in creating competitive advantage. Aftab Ahmed et al., 2019, intellectual capital shows a positive relationship.

Ravi Lankoni in his book "Firm Value" 2018 shows that there has been a paradigm shift about company theory in many perspectives. Corporate value no longer only involves the explicit relationships of various stakeholders such as shareholders and debt holders, but incorporates implicit relationships to be included in the value creation process. Various efforts of researchers to uncover determinants of company value. Frederico Belo Vito et al., 2019 found the results of his research that the importance of physical capital to assess companies declined in the last decade, while the importance of knowledge capital increased. On average physical capital accounts for $30 \%$ to $40 \%$ of the company's market value, installed labor accounts for $14 \%$ to $22 \%$, knowledge capital accounts for $20 \%$ to $43 \%$ and brand capital accounts for $6 \%$ to $25 \%$.

\subsection{Discussion}

The results of empirical studies show the importance of managing Intellectual capital for value creation such as case studies conducted by Nonaka and Takeuchi, 1995. Intellectual capital is capital to win the competition, Bontis, 1996. Intellectual capital is a hidden asset to maintain competitive advantage, Roos and Roos , 1997. Intellectual capital is corporate capital that can be converted into corporate value, Sveiby, 1998. The results of empirical studies show that there is a relationship between intellectual capital and firm value, such as the results of Johnson et al; 1999, Bounfour, 2003; Nuryaman, 2015; Appuhami and Bhuyan, 2015; Alste Kalvionyte and Renata Korsakiene, 2016; Costin Daraban, 2017; Aftab Ahmed, Muhammad Kashif Khurshid, Mohammad Usman Yousaf, 2019. The results of the study of Meditinos, et al., 2011; Mehralian, et al., 2012; shows there is no relationship between intellectual capital and firm value. Chang and Heish, 2011; Bentoen, 2012, shows a negative relationship between intellectual capital and value. The study of Khan and Raushan (2016) also does not show a significant relationship. The discussion proposed above shows the need for further research on the relationship of intellectual capital and firm value.

The importance of further research on the relationship of intellectual capital and value, encourages experts to create models of measurement and reporting of intellectual capital. Pulic, 
1998, developed a research model Value Added Intellectual Capital (VAIC) that measures the impact of managing Intellectual Capital, Ulum, et al., 2008. By managing intellectual capital, companies can innovate and express signals to the market about growth opportunities, Ståhle et al ., 2011; Sardo and Serrasqueiro., 2017; Smriti \& Das, 2018. Efforts to develop value added intellectual capital were carried out by Xu, J., \& Liu, F., 2020, by adding relation capital and innovation capital. Proxy of relation capital is the cost of marketing and advertising, while innovation capital is proxied by $R \& D$ expenses. So for value added modification is the sum of operating profit, depreciation, amortization, employee salaries and wages, marketing and advertising expenses, R\&D expenses.

\section{Conclussion}

The findings of this article will certainly make a strong contribution in the existing literature and provide a solid basis for research that uses intellectual capital as the main driver for value creation or not. Based on these findings it is concluded that more research is needed related to intellectual capital and firm value to clarify the role of intellectual capital in creating corporate value.

\section{References}

[1] Aftab Ahmed, Muhammad Kashif Khurshid, Mohammad Usman Yousaf, (2019) Impact of Intellectual Capital on Firm Value: The Moderating Role of Managerial Ownership, Article : Preprints (www.preprints.org) ; Posted: 31 January 2019 ; doi:10.20944/preprints201901.0318.v1

[2] Appuhami and Bhuyan. (2015) Examining the influence of corporate governance on intellectual capital efficiency: Evidence from top service firms in Australia. Managerial Auditing Journal, 30 (4/5), 347-372

[3] Bentoen. (2012), Influence Intellectual Capital Towards Financial Performance, Growth, and Market Value ". Article presented at Pelita Harapan University National Conference Surabaya.

[4] Bounfour. (2003),"The IC-dVAL approach", Journal of Intellectual Capital, Vol. 4 Iss: 3 pp. 396 - 413 , http://dx.doi.org/10.1108/14691930310487833

[5] Bounfour.A. Miyagawa .T. (Eds). Intangibles, Market Failure and Innovation Growth. Heidelberg:Springer Bontis. N, 1999. Managing Organizational Knowledge by Diagnosing Intellectual Capital : Framing and Advancing the State of the Field. International Journal of Technology Management. 18 (5-8): 433-462.

[6] Bontis, N. B \& Fitz-Enz, J. 2002. Intellectual Capital ROI a Causal Map of Human Capital Antecedents and Consequences. Journal of Intellectual Capital. 3 (3): 223-247.

[7] Bontis, N. 2004. National Intellectual Capital Index: a United Nations Initiative for the Arab Region.

[8] Journal of Intellectual Capital. 5 (1): 13-39

[9] Bukh. (2003), "The relevance of intellectual capital disclosure: a paradox?", Accounting,Auditing \& Accountability Journal, Vol.16 No.1, pp. 49-56 https://doi.org/10.1108/0951357031 0464273

[10] Chang and Heish. (2011)." The Price of Political Opposition: Evidence from Venezuela's Maisanta".

[11] American Economic Journal : Applied Economics. Vol. 3, No. 2, April 2011. Pp. 196 - 214.

[12] Chen, W,R. Gouma, B. Los and M. Timmer (2017), 'Measuring Income to Intangibles in Goods Production : A Global Value Chain Approach’, WIPO Economic Research Paper, N 36 , Geneva, WIPO. 5 Daraban, M. (2017). Economic Valu Added - a general concept review. "Ovidius" University Annals, 
[13] Economic Sciences Series, 168-173. Retrieved 11 20, 2017, from http://stec.univ-ovidius.ro/

[14] html/anale/ENG/2017/Section-III/9.pdf

[15] Daraban, M. C. (2017). Management Accounting as a Knowledge Based Organization Value Driver for the 21st Century Business. "Ovidius" University Annals, Economic Sciences Series, XVII(1/2017), 162-167. Retrieved 11 10, 2017, from http://stec.univovidius.ro/html/anale/RO/2017/Section- III/8.pdf.

[16] Edvinsson, L., Malone, M. S. 1997. Intellectual Capital: Realizing Your Company's True Value by Finding Its Hidden Brainpower. New York: HarperBusiness.

[17] Falato, Antonio, Dalida Kadyrzhanova, and Jae W. Sim (2014), "Rising Intangible Capital, Shrinking Debt Capacity, and the U.S. Corporate Savings Glut," Working paper, Federal Reserve Board of Governors.

[18] Frederico Belo Vito et al. (2019). "Decomposing Firm Value". For an overview of the firm valuation literature in Finance, Economics, and Accounting.

[19] Jensen and Meckling. (1976). "Theory of the firm: Managerial behavior, agency costs and ownership structure". Journal of Financsial Economics. Volume 3, Issue 4, October 1976, Pages 305-360

[20] Khan Ahmed Musa. (2018). "An Empirical Study of the Impact of Intellectual Capital on the Financial Performance of the Indian IT Sector". Journal of Corporate Finance Research. Volume 15, Issue 1, April 2018, Pages 7 - 19

[21] Lev. (2001).” Intangibles: Management, Measurement, and Reporting. Brookings Institution Press, Washington DC, 113-122.

[22] Medi tinos, et al., 2011. Medi tinos, Chatzoudes, Tsairidis, dan Theriou. - The impact of intellectual capital on firms' market value and financial performance.ll Journal of Intellectual Capital Vol. 12, no. 1 (2011): Pp. 132-151.

[23] Meglino, B. M., \& Ravlin, E. C. (1998). Individual values in organizations: Concepts, controversies, and research. Journal of Management, 24(3), 351-389. https://doi.org/10.1016/S0149- 2063(99)80065-8

[24] Mehralian, et al., (2012).“The Impact of Intellectual Capital Efficiency on Market Value: An Empirical Study from Iranian Pharmaceutical Companies”. Iranian journal of pharmaceutical research (IJPR). December 2012. 11(1). Pp. 195-207

[25] M.J. Langeveld. (1957)"Modern Educationalist of Everyday Upbringing". Education and the kyoto school of philosophy book : Pedagogy for human transformation . pp.133-146

[26] Nonaka, I., Takeuchi, H. (1995) The knowledge-creating company. How Japanese companies create the dynamics of innovation, Oxford University Press, Oxford.

[27] Nuryaman. (2015). "The Influence of Intellectual Capital on Firm's Value With The Finansial Performance as Intervening Variable.” Procedia - Social and Behavioral Sciences . 211 ( 2015 ). Pp $292-298$

[28] Petrash, Gordon. (1996). "Dow's journey to a knowledge value management culture," European Management Journal, Elsevier, vol. 14(4), pages 365-373, August.

[29] Pulic and Bornemann, M.and Leitner, K.H. (1999). Measuring and Reporting Intellectual Capital: The Case of A Research Technology Organization. Singapore Management Review. Vol. 24, No. 3.

[30] Ravi Lankoni. (2018). "Firm Value" . Reviewed: April 19th 2018Published: November 5 2018 DOI: 10.5772/intechopen.77342 Rokeach, M. (1973). The Nature o/Human Values. New York: The $\sim$ reePress

[30] Sardo and Serrasqueiro., (2017). “A European Empirical Study of the Relationship Between Firms' Intellectual Capital, Financial Performance and Market Value".Journal of Intellectual Capital 18(4) · July 2017 . DOI: 10.1108/JIC-10-2016-0105

[31] Smriti \& Das. (2018). "The impact of intellectual capital on firm performance: a study of Indian firms listed in COSPI". Journal of Intellectual Capital 19(1) · August 2018.

[32] Ståhle et al ., (2011). "Value Added Intellectual Coefficient (VAIC): a critical analysis". Journal of Intellectual Capital 12(4):247 - 268 · October 2011. DOI: 10.1108/14691931111181715.

[33] Steward. (1997). "Intellectual capital : the new wealth of organizations". Publisher : Div. of 
Bantam Doubleday Dell Publishing 1540 Broadway, New York, United State. ISBN. 978-0-38548228-8

[34] Sveiby. (1998). "Measuring Intangables \& Intellectual Capital - An Emerging First standard", http://www.sveiby.com/articles/Intangiblemethods.htm

[35] Sveiby. (2001). "Methods for Measuring Intangible Asstes", http://www.sveiby.com/ articles/ IntangibleMethods.htm.

[36] Xu, J., \& Liu, F. (2020). "The Impact of Intellectual Capital on Firm Performance: A Modified and Extended VAIC Model”.Journal of Competitiveness, 12(1), 161-176. https://doi.org/10.7441/ joc.2020.01.10

[37] Zhang, Lu (2005), "The Value Premium," The Journal of Finance, 60 (1), 67-103.

[38] Bounfour.A, (2018) "Africa: the next frontier for intellectual capital?", Journal of Intellectual Capital, Vol. 19 Issue: 3, pp.474-479, https://doi.org/10.1108/JIC-12-2017-0167 